\title{
The Role of Big Data and Cloud Computing for Technology Based Business
}

\author{
Leon Andretti Abdillah \\ Department of Information Systems \\ Universitas Bina Darma \\ Palembang, Indonesia \\ leon.abdillah@yahoo.com
}

\author{
Darmawan Baginda Napitupulu \\ Indonesian Institute of Sciences \\ Jakarta, Indonesia \\ darwan.na70@gmail.com \\ Janner Simarmata \\ State Univeristy of Medan \\ North Smatra, Indonesia \\ jannersimarmata@nimed.ac.id
}

Research Center for Quality System \& Testing Technology

\author{
Robbi Rahim \\ School of computer and communication engineering \\ Universiti Malaysia Perlis \\ Perlis, Malaysia \\ usurobbi85@zoho.com
}

Dahlan Abdullah

Department of Informatics Universitas Malikussaleh Aceh, Indonesia dahlan@unimal.ac.id

Andri Pranolo

Department of Informatics Universitas Ahmad Dahlan andri.pranolo@tif.uad.ac.id

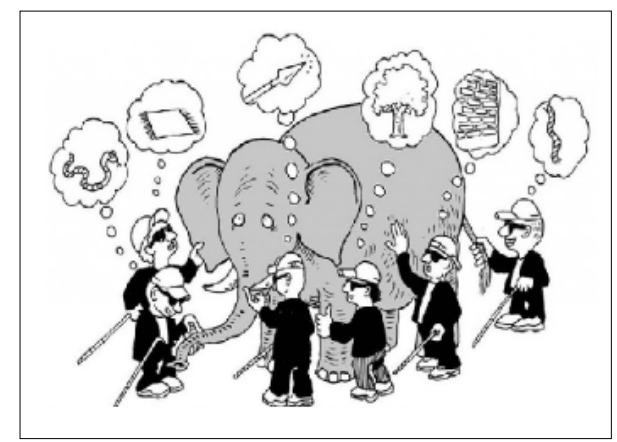

Fig. 1. An ilustration of big data concept

\section{INTRODUCTION}

Recent advancements in information technology (IT) such as internet have been created some new opportunities in many sectors. One of the most influential areas of IT development is in business. Daily transactions in a business requires a lot of activities involving large amounts of data. Modern business transactions move from conventional method into cyber era. In cyber era, almost of business transactions involving electronic processes. Every body able to browse, order and pay what they need by using small smartphone. The need for increasing data has led to a popular term with the term big data. Arguably, There are several ways big data [1] can be used to enhance a business, such as: 1) Saving money by leveraging big data technologies, 2) Making routine business decisions faster, 3) Supporting new types of decisions, and 4) Developing new products and services. Those business strategies were built around big data from the beginning, Fig. 1.
Big data is considered a strategic technology which is perceived as a source of competitive advantage for various businesses [2]. Big data concerns largevolume, complex, growingdata sets with multiple, autonomous sources [3]. The basic model of big data is HACE theorem. Big Data [4] starts with largevolume, Heterogeneous, Autonomous sources withdistributed anddecentralized control, and seeks to explore Complex and Evolving relationships among data (see Fig. 1). The consequence of big data is the need of very large storage media. Big companies have no difficulty in meeting the need for such huge storage media. For small and medium enterprise (SME), the ability to provide massive storage media is a very difficult thing.

In the current digital era, the need for services for many SME companies can be overcome by involving the paradigm of computing services in the form of cloud computing. 
Cloud Computing is a paradigm in which information is permanently stored in servers on the Internet and temporarily stored on the user's computer (client) including the desktop [5].Three most popular cloudparadigms include: 1) Infrastructure as a Service (IaaS), 2) Platform as a Service (PaaS), and 3) Software as a Service (SaaS) [6].Cloud computing provides an environment for small to medium sizedbusinesses to implement big data technology [7].With cloud technology, internet users from individuals, communities to companies can use applications without having to install on a local computer, access their personal files on any computer, anytime via internet access [5]. One example of Cloud computing topology is shown in Fig. 2.

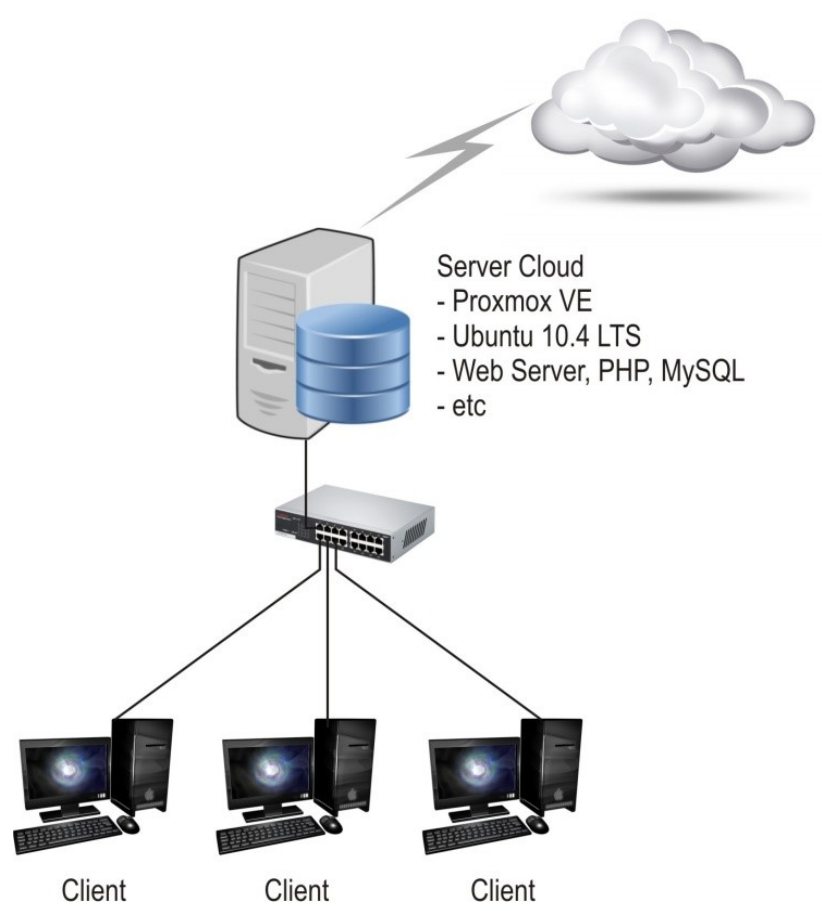

Fig. 2. An example of cloud computing concept

Along with the trend of information communication technology that involving smartphones, the cloud computing was much in touch with the smart mobile device. Mobile cloud compting (MCC) as the set of techniques that use cloud resources to empower mobile applications [8]. Figure 3 shows the architecture of mobile cloud computing.

One of the most popular famous trend in digital market is technology-based startup or cloud computing services in the field of e-commerce in Indonesia. Internet and smartphone have changed the behavior of people in shopping. At the moment there are many booming startup, Fig. 3.

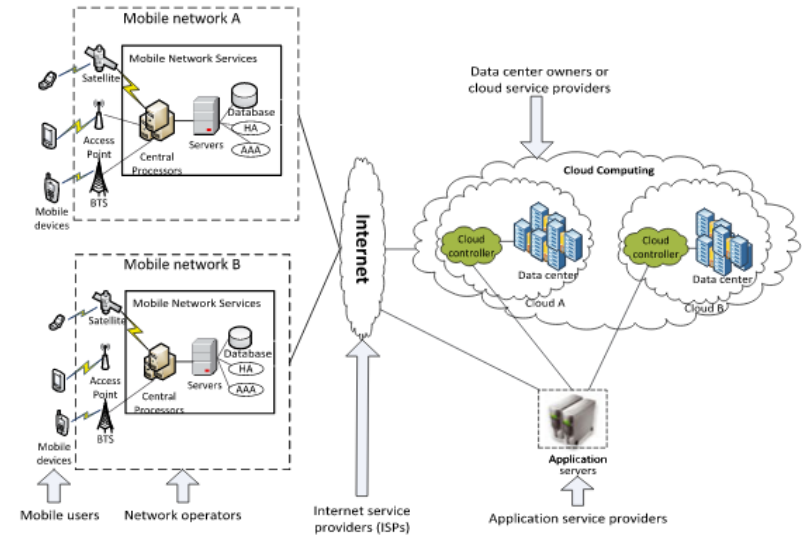

Fig. 3. Mobile cloud computing architecture.

This article describes the overview of cloud computing based companies in 3 (three) sectors: 1) Online Shopping Mall, 2) Online Transportation, and 3) Online Travel Agent.

The rest of this article are consist of 4 (four) more sections. Section 2 (two) describes online mall. Section 3 (three) describe online transportation. Section 4 (four) describes online travel agent. Last but not least is section 4 (four), conclussion. Section of conclusion summarize the article in a brief paragraph.

\section{ONLINE SHOPPING MALL}

Modern shopping places no longer have to be physical places. Information technology has opened a place of virtual sale. In the digital market method now, the transaction is done online, so it is known as online shopping term, Table I.

TABLE I. ONLINE SHOPPING MALL

\begin{tabular}{|l|l|l|}
\hline No & Name & Logo \\
\hline 1 & TokoPedia & \\
\hline 2 & Lazada & \\
\hline 3 & OLX &
\end{tabular}


The online shopping mall was showing incredible yearover-year growth and gaining traction in the countries of Indonesia, Malaysia, and Singapore [9].Online shopping provides trading and transaction facilities supported by banking. by involving transactions through online payment via bank, it can increase the level of convenience and ease in making payments.

Indonesian ecommerce is one of the most talked about spaces in Southeast Asia's tech startup world [10]. This section involves 3 (three) cloud computing services (online shopping sites) in the field of e-commerce in Indonesia, such as: 1) TokoPedia, 2) Bukalapak, and 3) OLX. Table 1 shows some of popular online shopping malls in Indonesia.

\section{A. TokoPedia}

Tokopedia is one of the biggest online mall in Indonesia.

Tokopedia provides a means of selling from customer to customer where anyone can open an online store that serves potential buyers from all over Indonesia. Tokopedia was fonded in 2009 and has a staff of over 200 [11]. In a research [12], Tokopedia.com's respondents that are more likely to buy fashion product category. Today, tokopedia has become an online store for everyone who wants to open a virtual business, Fig. 4.
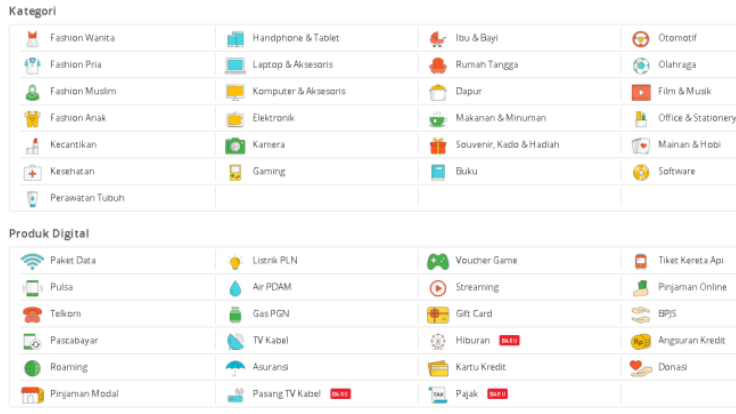

Fig. 4. TokoPedia categories and digital products

Nowadays, Tokopedia provides not less than 19 categories and 17 types of digital products (see Fig. 4). Tokopedia also famous in mobile commerce application.

Tokopedia,Indonesia's largest marketplace, is the first digital market in ASEAN region that secure US\$100 million injection [13] from Softbank (Japanese telecommunications and internet service company), Sequoia Capital (American venture capital firm, an early investor in technology giants like Apple, Google, Yahoo and Oracle) [14] and SB Pan Asia [13].

\section{B. Bukalapak}

Bukalapak is one of the leading online marketplace in Indonesia. Just as a buying and selling service site provides a means of buying and selling from consumers to consumers (consumers to consumers business model).Anyone can open an online store in Bukalapak and serve buyers from all over Indonesia for many or many unit transactions.Bukalapak founded by Achmad Zaky in 2010 has experienced significant growth. Bukalapak has mission of promoting SMEs - SME (Small and Medium Enterprises) in Indonesia and become the market place number one choice of Indonesian society [15].
Bukalapak has a high commitment to promote SMEs. By online promotion, SMEs can meet the demand of the buyers [16] that always changing according to the demographic characteristics of the buyers. At this time Bukalapak provide at least 20 (twenty) categories of products that can be accessed via general smartphone.

\section{C. $O L X$}

The site began back in 2003 as TokoBagus. Online stores are required to develop various strategies to survive in online stores industry due to increasing competition [17].In 2014, it changed its name to OLX Indonesia, and later it merged with competitor Berniaga [10]. And now, OLX is the largest online classifieds "iklan baris" site in Indonesia.

\section{ONLINE TRANSPORTATION}

The second technology based business is transportation sector. There are 3 (three) famous smartphone-based applications in online transportations: 1) Go-Jek, 2) Grab, and 3) Uber. Table II shows some of top online transportation services in Indonesia.

TABLE II. ONLINE TRANSPORTATION SERVICES

\begin{tabular}{|l|l|l|}
\hline No & Name & Logo \\
\hline 1 & Go-Jek & \\
\hline 2 & Grab & \\
\hline 3 & & \\
\hline
\end{tabular}

\section{A. Go-Jek}

Go-Jek is the most popular online transportation services in Indonesia [18]. Go-Jek has a very handy menu section for gojek users like: "go-ride", "go-send", "go-mart", "go-food", "gobox", "goclean", "go-glam", "go-massage", "go-busway", and "go-tix" [19]. Go-Jek offers innovative means of transportation that provide security for its customers [20], and easy to use by every body.

\section{B. Grab}

Grab is an online transport service, it was established in Malaysia in 2012. Grab has a promo to bind its customers, such 
as getting a discount when top-up balance in such a high amount balance [21]. As one of Asia's most successful startups [22], grab provides any services including: 1) GrabTaxi, 2) GrabCar, 3) GrabShare, 4) GrabBike, 5) GrabExpress, 6) GrabFood, 7) GrabHitch Bike, 8) GrabHitch Car, and 9) GrabRental, Fig. 5.

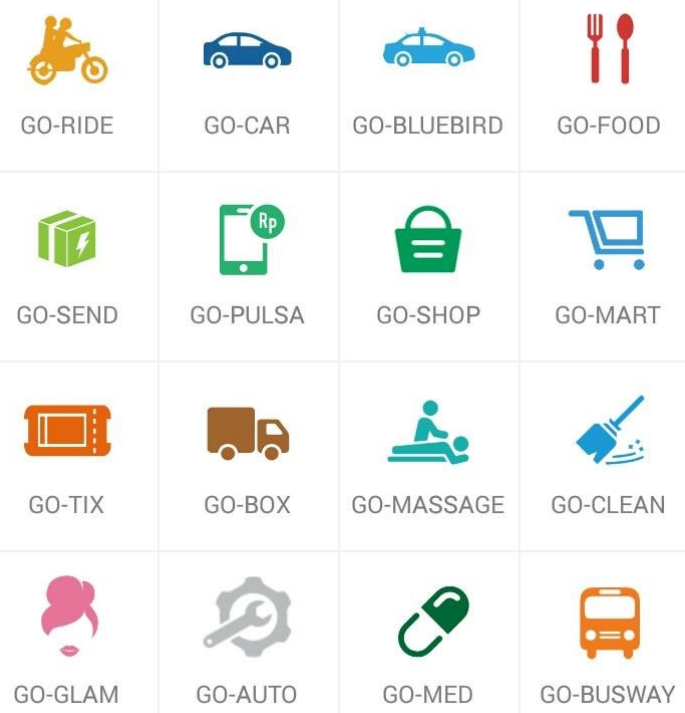

Fig. 5. Gojek services on Android app

\section{Uber}

Uber begins with the sharing of assets in the form of a car vehicle. Colloquially known as "ridesharing" [23]. Information technology facilitate transactions between vehicle ownersand people who would like to use those vehicles for short periods of time [24].

\section{ONLINE TRAVEL AgENT}

The last sector of technology based business cover in this article is online travel agent also known as OTA. There are 3 (three) famous application in online travel agents: 1) Traveloka, 2) Tiket, and 3) Pegi-pegi. See Table III for the icons of those OTA.

TABLE III. OINLINE TRAVEL AgENTS

\begin{tabular}{|c|c|c|}
\hline No & Name & Logo \\
\hline 1 & Traveloka & \\
\hline 2 & Tiket & \\
\hline 3 & Pegi-pegi & \\
\hline
\end{tabular}

\section{A. Traveloka}

Traveloka is one of online travel agent that is most widely used by millennium generation with the percentage of $84 \%$ [25]. This top of mind OTA offers benefits [26] to make it easier to choose the mode of transport, booking information, and a variety of tourist destinations.

Traveloka, which was originally launched as an airline ticket search site, has grown with a number of new services such as: Flight Tickets, Hotels, Train, Flight + Hotel, Top-up \& Data, Attractions \& Activities, Fig. 6.

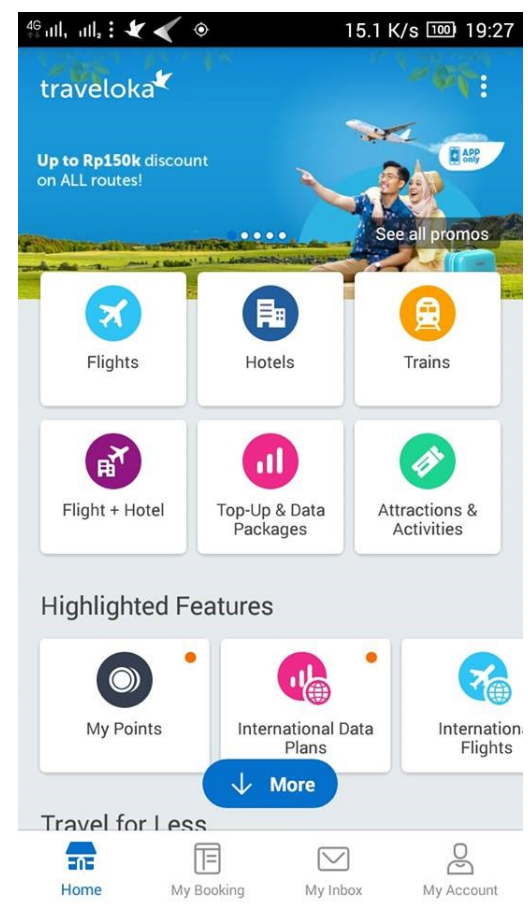

Fig. 6. Traveloka services on Android app

\section{B. Tiket}

One of the main activities in tourism is visiting places of interest. tourist destinations are often far away and require special modes to reach them.one of the popular online applications in the provision of tickets is Tiket.com.

Tiket.com is one of the largest ticket providers in Indonesia. Tiket.com provides APIs for mashup application. Mashup [27] is a web page or an application that combines a variety of online data and display it into a new form of information. This API can be accessed by developers to access and process services owned by Tiket.com.With the API, then other applications can sell tickets from Tiket.com to its customers.

\section{Pegi-pegi}

Pegipegi.com is one OTA based in Indonesia and serves customers directly or Business to Customer (B2C). The implementation of $\mathrm{B} 2 \mathrm{C}$ e-commerce has increased the market sale and for long term of company development [28]. Pegipegi.com is one of the ongoing online hotel booking websites. Pegipegi as one of local online intermediary industry 
player [29] compete to get most local and international travelers.

\section{CONCLUSIONS}

Big data and cloud computing has been proved to have a significant role in supporting the development of the business world. Through cloud computing, the cost of IT for many company's business are reduced significantly. Cloud computing technology open new challenges for business in many sectors (market places, transportation, travel agent, etc.). Cloud computing adoption by SME's e-commerce [30] will make significant changes in the business enterprises.All cloud computing-based businesses can be accessed using smartphones, both based on the iPhone and Andorid. Furthermore, all current modern marketplaces businesses have access to the most popular social media like facebook [31]. Combination of cloud computing, big data and social technologies [32] have been reached millions of people arround the world.

\section{REFERENCES}

[1] T. Davenport, Big data at work: dispelling the myths, uncovering the opportunities: harvard Business review Press, 2014.

[2] V. F. Brock and H. U. Khan, "Are enterprises ready for big data analytics? A survey-based approach," International Journal of Business Information Systems, vol. 25, pp. 256-277, 2017.

[3] X. Wu, et al., "Data mining with big data," IEEE Transactions on Knowledge and Data Engineering, vol. 26, pp. 97-107, 2014.

[4] D. S. Tamhane and S. N. Sayyad, "Big data analysis using hace theorem," International Journal of Advanced Research in Computer Engineering \& Technology (IJARCET) Volume, vol. 4, pp. 2278-1323, 2015.

[5] Fikri, et al., "Perancangan Teknologi Cloud untuk Penjualan Online Kain Songket Palembang," in Seminar Nasional Sistem Informasi Indonesia ke-8 (SESINDO2015), Institut Teknologi Sepuluh Nopember (ITS), Surabaya, 2015, pp. 387-392.

[6] D. Agrawal, et al., "Big data and cloud computing: current state and future opportunities," in Proceedings of the 14th International Conference on Extending Database Technology, 2011, pp. 530-533.

[7] B. M. Purcell, "Big data using cloud computing," Journal of Technology Research, vol. 5, p. 1, 2014.

[8] M. R. Rahimi, et al., "Mobile cloud computing: A survey, state of art and future directions," Mobile Networks and Applications, vol. 19, pp. 133-143, 2014.

[9] K. Eckard, et al. (2015). Rocket Internet: Clone Factory or Long-Term Stakeholder? Available: http://fletcher.tufts.edu/ /media/Fletcher/MIB/pdfs/B236\%20Student\%2 0Case $\% 20$ Studies/Rocket\%20Internet.pdf

[10] L. Cosseboom. (2015). 28 popular online shopping sites in Indonesia. Available: https://www.techinasia.com/popular-online-shoppingplatforms-in-indonesia

[11] M. Pangestu and G. Dewi, "13 Indonesia and the digital economy: creative destruction, opportunities and challenges," Digital Indonesia: Connectivity and Divergence, p. 227, 2017.

[12] H. H. V. Gaffar and M. Atrisia, "Demography, Motivation, and Satisfaction of E-Commerce Customer on OLX. co. id and Tokopedia. com," in Int'l Conference on Business, Marketing \& Information System Management (BMISM'15), Paris, France, 2015.

[13] F. Hoppe, et al. (2016). Can Southeast Asia Live Up to Its E-commerce Potential? Available: http://zenithinfobank.com/wpcontent/uploads/2016/05/BAIN_BRIEF_Can_Southeast_Asia_Live_Up _to_Ecommerce_potential.pdf

[14] W. A. A. D. Gelles. (2014). In WhatsApp Deal, Sequoia Capital May Make 50 Times Its Money. Available: https://dealbook.nytimes.com/2014/02/20/in-whatsapp-deal-sequoiacapital-may-make-50-times-its-money/

[15] U. Yunus, "Enhance The Brand Image Through Television Commercial (Tvc): A Case Study "Create Your Chance" of Tokopedia. Com and Apologizes of Bukalapak. Com," Humaniora, vol. 7, pp. 569-576, 2016.

[16] Y. Astuti, et al., "Development Strategy for Improving Local Economy Potential: A Case Study of Binong Jati Knitting Industrial Center, Bandung-Indonesia," International Journal of Basic and Applied Science, vol. 4, pp. 59-68, 2016.

[17] A. Wardhana and M. Pradana, "Viral Marketing Determinants of Top Online Shop Brands in Indonesia," MIMBAR, Social and Development Journal, vol. 32, pp. 25-30, 2016.

[18] C. Wulandari, et al., "Analisa Tingkat Kepuasan Layanan TI (Studi Kasus pada Aplikasi Gojek)," in Seminar Nasional Teknologi Informasi dan Komunikasi ke-8 (SEMNASTIK2016), Palembang, 2016.

[19] T. Oktaviana, et al., "Analisis Aplikasi Gojek dengan Menggunakan Metode Usability di Palembang," in Seminar Nasional Teknologi Informasi dan Komunikasi ke-8 (SEMNASTIK2016), Palembang, 2016.

[20] W. Anindhita, et al., "Analisis Penerapan Teknologi Komunikasi Tepat Guna Pada Bisnis Transportasi Ojek Online (Studi pada Bisnis Gojek dan Grab Bike dalam Penggunaan Teknologi Komuniasi Tepat Guna untuk Mengembangkan Bisnis Transportasi)," in Seminar Nasional INDOCOMPAC, Jakarta, 2016.

[21] H. L. H. S. Warnars, et al., "Smart Integrated Payment System for Public Transportation in Jakarta," Bulletin of Electrical Engineering and Informatics, vol. 6, pp. 241-249, 2017.

[22] M. Lin and C. W. Dula, "Grab Taxi: Navigating new frontiers," Asian Management Insights, vol. 3, pp. 40-45, 2016.

[23] V. D. Ngo, "Transportation network companies and the ridesourcing industry: a review of impacts and emerging regulatory frameworks for Uber," University of British Columbia, 2015.

[24] J. M. Barry and P. L. Caron, "Tax regulation, transportation innovation, and the sharing economy," U. Chi. L. Rev. Dialogue, vol. 82, p. 69, 2015.

[25] Y. Pratika and B. Bayu, "An Examination of E-Loyalty of Indonesian Millennial Traveler on The Using of Online Travel Agent (OTA)," PEOPLE: International Journal of Social Sciences, vol. 3, 2017.

[26] A. Nugroho, "ASEAN Tourism Marketing Communication Attribute: An Exploratory Research at Goaseantv," European Research Studies, vol. 20, p. 383, 2017.

[27] Y. Setiowati, et al., "M-Trav: Application of Tour Guide in Indonesia with RSS Services Based Mobile," in International Conference on Electrical Engineering, Informatics, and Its Education (CEIE2015), Malang, 2015.

[28] D. L. Paris, et al., "Exploring Implementation Factors Influencing Business-to-Customer (B2C) e-Commerce," Advanced Science Letters, vol. 21, pp. 1455-1459, 2015.

[29] H. M. Septiadi, et al., "Prediction Models Based on Flight Tickets and Hotel Rooms Data Sales for Recommendation System in Online Travel Agent Business," in The 7th Smart Collaboration for Business in Technology and Information Industries (SCBT12016), Bandung, 2016.

[30] J. P. Shah, "Role and Challenges in Cloud Computing and E-commerce in SME's," RESEARCH HUB-International Multidisciplinary Research Journal, vol. 1, 2014.

[31] L. A. Abdillah, "Exploring Student's Blended Learning Through Social Media," ComTech (Computer, Mathematics and Engineering Applications), vol. 7, pp. 245-254, 2016.

[32] L. A. Abdillah, "Enriching Information Technology Course Materials by Using Youtube," in The 5th International Conference On Artificial Intelligence, Computer Science and Information Technology (AICSIT2017), Bayview Beach Resort, Batu Ferringhi, Pulau Pinang, Malaysia, 2017, pp. 75-82. 